\title{
Implementasi Model Pembelajran Kooperatif Tipe STAD dengan Media Gambar untuk Meningkatkan Prestasi Belajar IPS
}

\section{Made Suantara*}

\section{A R T I C L E I N F O}

Article history:

Received 19 August 2019

Received in revised form

30 September 20189

Accepted 10 October 2019

Available online 29

November 2019

\section{Kata Kunci:}

Model Pembelajaran

Kooperatif tipe STAD,

Media Gambar, Prestasi

Belajar.

Keywords:

STAD type Cooperative Learning Model, Image

Media, Learning

Achievement.

\begin{abstract}
A B S T R A K
Penelitian tindakan kelas ini dilaksanakan di SD Negeri 3 Ubud tahun pelajaran 2018/2019 semester II dengan tujuan untuk meningkatkan prestasi belajar IPS siswa kelas III A SD Negeri 3 Ubud melalui penerapan model pembelajaran Kooperatif tipe STAD dengan media gambar. Subjek penelitian ini adalah siswa kelas III A SD Negeri 3 Ubud yang berjumlah 34 orang dalam mata pelajaran IPS. Data tentang prestasi belajar siswa diperoleh dengan menggunakan metode tes dengan instrumanya yaitu berupa tes prestasi belajar. Data tersebut kemudian dianalisis dengan menggunakan teknik analisis deskriptif kuantitatif. Hasil penelitian ini adalah Penerapan model pembelajaran Kooperatif Tipe STAD dengan media gambar dapat meningkatkan prestasi belajar IPS siswa kelas III A SD Negeri 3 Ubud pada semester II tahun pelajaran 2018/2019. Skor rata-rata prestasi belajar siswa menunjukkan adanya peningkatan dari siklus I ke siklus II. Rata-rata kelas prestasi belajar pada awal pembelajaran hanya mencapai 60,00 , siklus I meningkat menjadi 69,11 pada siklus II menjadi 78,52. Ketuntasan klaksikal awal hanya mencapai $26,47 \%$, pada siklus I meningkat menjadi $73,52 \%$ dan pada siklus II menjadi $94,11 \%$.
\end{abstract}

\section{A B S T R A C T}

This class action research was conducted at SD Negeri 3 Ubud in the second semester of 2018/2019 in the second semester with the aim of improving social studies learning achievement of students in class III $A$ at SD Negeri 3 Ubud through the application of the STAD type Cooperative learning model with image media. The subjects of this study were 34 students in class III A, SD Negeri 3 Ubud, in social studies subjects. Data about student achievement is obtained using the test method with the instrument in the form of a learning achievement test. The data is then analyzed using quantitative descriptive analysis techniques. The results of this study are the application of the STAD Type Cooperative learning model with media images can improve social studies learning achievement of students in class III A of SD Negeri 3 Ubud in the second semester of the 2018/2019 academic year. The average score of student achievement shows an increase from cycle I to cycle II. The average grade of learning achievement at the beginning of learning only reached 60.00 , the first cycle increased to 69.11 in the second cycle to 78.52 . Initial claxical completeness only reached $26.47 \%$, in the first cycle increased to $73.52 \%$ and in the second cycle to $94.11 \%$. 


\section{Pendahuluan}

Pendidikan merupakan sesuatu yang memiliki tujuan yang sangat penting untuk diperoleh. Dalam skala nasional, tujuan dalam pendidikan adalah untuk mengembangkan kemampuan dan membentuk watak serta peradaban bangsa yang bermartabat dalam rangka mencerdaskan kehidupan bangsa, serta untuk mengembangkan potensi peserta didik agar menjadi manusia yang beriman dan bertakwa kepada Tuhan Yang Maha Esa, berakhlak mulia, sehat, berilmu, cakap, kreatif, mandiri, dan menjadi warga negara yang demokratis serta bertanggung jawab. Artinya bahwa tujuan pendidikan adalah membentuk orang yang mempunyai sikap atau attitude sosial yang baik, yang mampu bekerja sama dengan lingkungannya, mampu mengutamakan kepentingan umum dari pada kepentingan sendiri atau golongan. Sedangkan fungsi diadakannya pendidikan dalam pandangan dalam Islam

Tidaklah jauh berbeda dengan yang ada pada tujuan pendidikan nasional di atas, dimana pendidikan tidak hanya untuk pembentukan akal atau pengembangan kompetensi para siswa saja, melainkan berfungsi juga kepada setiap bagian jiwa sehingga setiap bagian jiwa itu menjadi mampu melaksanakan tugasnya sebagaimana yang dikehendaki Allah SWT. Dalam proses pencapaian tujuan pendidikan, siswa sebagai subyek pendidikan dapat diarahkan kepada suatu pendidikan formal dan informal. Pendidikan formal merupakan suatu jalur pendidikan yang terstruktur dan berjenjang yang terdiri atas pendidikan dasar, pendidikan menengah, dan pendidikan tinggi. Sedangkan pendidikan informal adalah jalur pendidikan di luar pendidikan formal. Dalam arti tidak dilaksanakan secara struktur dan berjenjang seperti bimbingan-bimbingan belajar, kursus, dan lain sebagainya (Thahir, 2014).

Pendidikan merupakan suatu proses di mana pengalaman dan informasi diperoleh sebagai hasil belajar, yang mencakup pengertian dan penyesuaian diri dari pihak peserta didik terhadap rangsangan yang diberikan kepadanya menuju ke arah pertumbuhan dan perkembangan. Dengan demikian, pendidikan di sekolah dipengaruhi oleh beberapa faktor antara lain: guru, metode/pendekatan/model pembelajaran, kurikulum, media pengajaran, dan peserta didik. Dalam rangka meningkatkan mutu pendidikan di Indonesia diperlukan upaya yang serius untuk meningkatkan kualitas guru. Seorang guru memiliki peran yang paling besar dalam upaya inovasi serta peningkatan mutu pendidikan melalui inovasi dalam proses pembelajaran. Peningkatan mutu pendidikan dapat dimulai dengan meningkatkan mutu guru dalam mengajar dan berprilaku profesional. Berbagai penataran dan pelatihan guru menjadi salah satu bentuk dari upaya tersebut walaupun kurang membekas dalam keseharian aktivitas guru. Hal inilah yang mendasari perlunya perbaikan yang menitikberatkan kepada kondisi nyata di lapangan, mulai dari kondisi di kelas, sekolah, dan guru. Pelaksanaan sertifikasi guru sebagai amanat dari Undangundang (UU) Nomor 14 Tahun 2005 tentang Guru dan Dosen diharapkan berperan dalam peningkatan kualitas pendidikan (Monawati, 2016).

Dalam pelaksanaan pembelajaran disekolah, usaha untuk meningkatkan prestasi belajar siswa banyak mengalami kendala dan hambatan. Lebih-lebih pada mata pelajaran IPS yang menuntut begitu banyak pencapaian konsep sehingga mengakibatkan motivasi belajar kurang baik. Motivasi belajar dapat dipengaruhi oleh faktor internal yaitu kemampuan yang berasal dari siswa, yang meliputi kecerdasan, bakat, minat, motivasi dan emosi. Dan juga dipengaruhi oleh faktor eksternal berasal dari luar, meliputi lingkungan keluarga, sekolah, dan masyarakat.

Peran siswa dalam konteks pembelajaran konstruktivisme ketika pembelajaran berpusat pada siswa adalah belajar dan mencari sendiri arti dari materi yang mereka pelajari yang merupakan proses penyesuaian konsep dan ide-ide baru dengan kerangka berpikir yang telah ada dalam pikiran mereka dan siswa sendirilah yang bertanggung jawab atas prestasi belajarnya. Degeng $(2000 ; 7)$ menyatakan pada dimensi Kontruktivistik, pembelajaran lebih banyak diarahkan untuk meladeni pertanyaan atau pandangan siswa. Dengan demikian, aktivitas belajar lebih didasarkan pada data primer dan bahan manipulatif dengan penekanan pada keterampilan berpikir kritis, seperti; analisis, membandingkan, generalisasi, memprediksi, dan mengipotesis. Jadi tujuan pembelajaran kontruktivistik sangat menekankan pada proses pembelajaran disamping juga prestasi belajar siswa. Suatu tujuan pembelajaran dapat tercapai sesuai dengan yang diharapkan apabila model pembelajaran yang sesuai dengan materi yang diberikan oleh seorang guru. Dengan demikian pemilihan sebuah model pembelajaran merupakan bagian penting dalam merencanakan atau mendesain pembelajaran, agar terjadi interaksi antara siswa dengan guru, siswa dengan siswa maupun siswa dengan sumber belajar lainnya

Menurut Aunurrahman, (2009: 176) keberhasilan proses pembelajaran merupakan muara dari seluruh aktivitas yang dilakukan guru dan siswa, artinya apapun bentuk kegiatan-kegiatan guru mulai dari merancang pembelajaran, memilih dan menentukan materi, pendekatan, strategi dan metode pembelajaran, memilih dan menggunakan teknik evaluasi semua disarankan untuk mencapai keberhasilan belajar siswa. 
Art dan Newman dalam Puspasari (2003 : 12) menyatakan, bahwa "Model pembelajaran kooperatif adalah model pembelajaran yang terdiri atas kelompok kecil yang bekerja sama sebagai satu tim untuk memecahkan masalah, melengkapi tugas atau menyelesaikan tugas bersama". Hal ini sejalan dengan pendapat Lie (2002 : 12) yang menyatakan, bahwa "Pembelajaran kooperatif adalah pembelajaran yang memberi kesempatan kepada anak didik untuk bekerja sama dalam tugas-tugas yang terstruktur". Sedangkan Johnson and Johnson (dalam Puspasari, 2003 : 12) menyatakan, bahwa "Pembelajaran kooperatif adalah suatu model diskusi yang dibimbing guru, terdiri dari beberapa kelompok di dalam kelas, satu kelompok terdiri dari empat atau lima orang saja" (Maulana, 2017).

Student Teams Achievement Division (STAD) merupakan salah satu strategi pembelajaran kooperatif yang di dalamnya beberapa kelompok kecil siswa dengan level kemampuan akademik yang berbeda-beda saling bekerja sama untuk menyelesaikan tujuan pembelajaran. Tidak hanya secara akademik, siswa juga dikelompokkan secara beragam berdasarkan gender, ras, dan etnis (Rusman, 2012, hal. 201). Dengan heterogenitas anggota dalam satu kelompok, diharapkan dapat memotivasi siswa yang berkemampuan lebih dengan siswa yang berkemampuan kurang dalam menguasai materi, sehingga tumbuh kesadaran dalam diri siswa bahwa belajar dengan model kooperatif tipe STAD cukup menyenangkan. STAD terdiri dari lima komponen utama yaitu: (1) presentasi kelas, (2) belajar dalam kelompok, (3) tes individu, (4) penghargaan kelompok (Slavin, 2005, hal. 73). Kelebihan dari STAD adalah, dengan adanya tes individu yang berupa kuis, dapat meningkatkan tanggung jawab individu, karena nilai akhir kelompok dipengaruhi nilai kuis yang dikerjakan secara individu sehingga membuat siswa lebih termotivasi dalam mengikuti proses pembelajaran Menurut Raymond dan Judith (2004, hal 11) menyatakan motivasi belajar adalah suatu nilai dan suatu dorongan untuk belajar, anak tidak hanya sudi belajar tetapi juga menghargai dan menikmati aktivitas belajar seperti mereka menghargai dan menikmati hasil belajarnya. Motivasi berhubungan erat dengan minat. Peserta didik yang memiliki minat lebih tinggi pada suatu mata pelajaran cenderung lebih memiliki perhatian yang lebih terhadap mata pelajaran tersebut, akan menimbulkan motivasi yang lebih tinggi dalam belajar (Purwanti, 2018).

Keunggulan pembelajaran koopertatif tipe STAD terletak pada langkah-langkah pembelajaran yang diterapkan. Penerapan model pembelajaran kooperatif tipe STAD diharapkan mampu meningkatkan hasil belajar siswa. Keunggulan pembelajaran kooperatif tipe STAD yaitu siswa bekerja dalam kelompok sehingga siswa dapat memahami konsep materi yang ada dengan bantuan teman kelompok mereka. Hal ini diperkuat dalam hasil penelitian Asdar (2009) pembelajaran kooperatif tipe STAD, bekerja dalam kelompok sehingga siswa dapat menumbuhkan kemauan kerja sama, berpikir kritis, termotivasi, bertanggung jawab terhadap kelompok. Siswa memiliki kemampuan untuk membantu teman dan terhadap diri sendiri dalam mengikuti kuis nantinya guna mencapai suatu tujuan yaitu mendapatkan penghargaan tim yang super. Adanya evaluasi, siswa mampu merangkum pelajaran yang diterima dari penjelasan guru maupun hasil kerja kelompok yang dilakukan. Guru mengevaluasi hasil belajar tentang materi yang telah dipelajari dimana siswa tidak diperbolehkan bekerja sama (Wardana, 2017).

Namun demikian, kenyataan yang terjadi di lapangan sangat jauh dari harapan kita semua. Prestasi belajar IPS siswa di SD Negeri 3 Ubud sangat jauh dari nilai KKM yang ditentukan untuk mata pelajaran ini yaitu 70,00. Nilai rata-rata siswa yang diperoleh hanya mencapai 60,00 dan prosentase ketuntasan mata pelajaran IPS siswa kelas III A semester II tahun pelajaran 2018/2019 hanya mencapai 26,47\%

Melihat kenyataan ini, peneliti dalam hal ini adalah guru di sekolah ini harus melakukan pembenahan strategi pembelajaran untuk memperbaiki prestasi belajar IPS khususnya.Untuk itu peneliti melaksanakan pembelajaran dengan penerapan model pembelajaran Kooperatif tipe STAD dengan media gambar. Dengan model pembelajaran ini peneliti sangat berharap prestasi belajar IPS siswa dapat ditingkatkan.

Berdasarkan latar belakang di atas, maka pada penelitian ini akan mengambil judul tentang Implementasi Model Pembelajran Kooperatif Tipe STAD dengan Media Gambar Untuk Meningkatkan Prestasi Belajar IPS Siswa Kelas III A Semester II SD Negeri 3 Ubud Tahun Pelajaran 2018/2019.

\section{Metode}

Penelitian yang dilakukan termasuk penelitian tindakan. Oleh karenanya, rancangan yang khusus untuk sebuah penelitian tindakan sangat diperlukan. Peningkatan diri untuk hal yang lebih baik ini dilakukan terus menerus sampai tujuan tercapai (Suharsimi Arikunto, Suhardjono, Supardi, 2006: 6-7).

Dalam melaksanakan penelitian, rancangan merupakan hal yang sangat penting untuk disampaikan. Tanpa rancangan, bisa saja alur penelitian akan ngawur dalam pelaksanaannya.

Secara operasional prosedur dasar pengembangan tindakan yang akan dilakukan dapat dijabarkan sebagai berikut. 


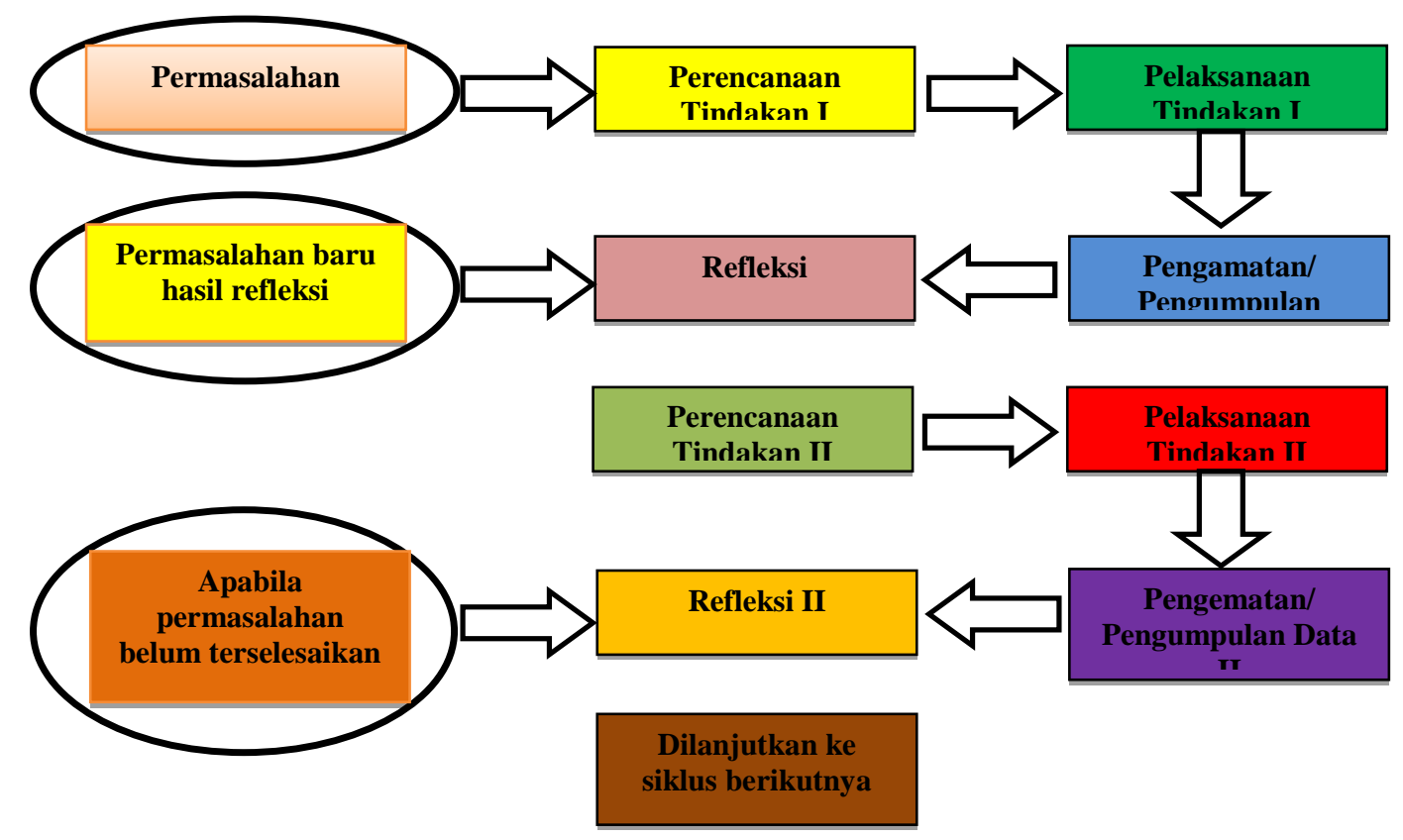

Gambar 1. Penelitian Tindakan Model Arikunto, Suharsimi, 2007

Tahap pelaksanaan tindakan dilakukan dengan pembelajaran di kelas. Pada tahap ini guru peneliti giat melakukan tindakan menggunakan model pembelajaran kooperatif tipe STAD dengan media gambar. Rancangan tindakan tersebut sebelumnya telah dilatih untuk dapat diterapkan di dalam kelas sesuai dengan skenarionya. Skenario dari tindakan diupayakan dilaksanakan dengan baik dan wajar.

Tahap ini sebenarnya berjalan bersamaan dengan saat pelaksanaan. Pengamatan dilakukan pada waktu tindakan sedang berjalan, jadi, keduanya berlangsung dalam waktu yang sama. Pengamatan juga dilakukan setelah kegiatan selesai yaitu pada saat diadakan kegiatan tes. Guru memperhatikan proses yang sedang berlangsung, memperhatikan keaktifan siswa dan guru menilai sikap siswa saat menjawab soal. Pada tahap ini, guru yang bertindak sebagai peneliti melakukan pengamatan dan mencatat semua hal yang diperlukan dan terjadi selama pelaksanaan tindakan berlangsung. Pengumpulan data ini dilakukan dengan menggunakan tes prestasi belajar yang telah tersusun, termasuk juga pengamatan secara cermat pelaksanaan skenario tindakan dari waktu ke waktu serta dampaknya terhadap proses dan prestasi belajar siswa.

Tahapan ini dimaksudkan untuk mengkaji secara menyeluruh tindakan yang telah dilakukan, berdasarkan data yang telah terkumpul, kemudian dilakukan evaluasi guna menyempurnakan tindakan berikutnya. Refleksi dalam PTK mencakup analisis, sintesis, dan penilaian terhadap hasil pengamatan atas tindakan yang dilakukan. Jika terdapat masalah dari proses refleksi maka dilakukan proses pengkajian ulang melalui siklus berikutnya yang meliputi kegiatan: perencanaan ulang, tindakan ulang, dan pengamatan ulang sehingga permasalahan dapat teratasi

\section{Hasil dan Pembahasan}

Hasil yang menunjukan perolehan nilai rata rata kelas prestasi belajar IPS masih sangat rendah, yaitu dengan perolehan skor nilai secara klasikal yaitu 2040 dan rata rata hanya mencapai 60,00, dimana siswa yang mencapai persentase ketuntasan belajar 26,47\%, dan yang tidak mencapai ketuntasan adalah 73,52\%, dengan tuntutan KKM untuk mata pelajaran IPS di kelas III A SD Negeri 3 Ubud adalah dengan nilai 70,00 .

1) Hasil pada siklus I

Pada siklus I sudah diupayakan untuk perbaikan pembelajaran untuk meningkatkan prestasi belajar IPS dengan menggunakan model pembelajaran Kooperatif tipe STAD dengan media gambar. Peneliti telah giat melakukan kegiatan yang susuai dengan kebenaran teori yang ada sehingga peneliti memperoleh hasil yang lebih baik dari proses awal, yaitu dengan rata rata nilai 69,11 dari jumlah nilai 2350 seluruh siswa di kelas III A SD Negeri 3 Ubud, dan prosentase ketuntasan belajarnya adalah 73,52\%, yang tidak tuntas adalah 26,47\%. Hasil ini belum maksimal, karena belum mecapai indikator keberhasilan penelitian yang mencanangkan dengan minimal prosentase ketuntasan belajar $85 \%$. 
2) Hasil Pada siklus II,

Dengan tindakan yang sangat maksimal dan pelaksanaan yang betul-betul mengikuti kebenaran teori sesuai dengan model pembelajaran Kooperatif tipe $S T A D$ dengan media gambar dalam pembelajaran IPS di kelas III A SD Negeri 3 Ubud, dimana hasil yang diperoleh pada siklus II ini ternyata prestasi belajar IPS meningkat secara signifikan dengan nilai rata-rata 78,52, dan ketuntasan belajarnya adalah $94,11 \%$.

Semua hasil yang diperoleh dari awal, siklus I dan siklus II digambarkan dalam bentuk tabel dan grafik seperti berikut:

Tabel 1. Tabel Data Prestasi belajar Siswa Kelas III A SD Negeri 3 Ubud

\begin{tabular}{lllll}
\hline DATA & AWAL & SIKLUS I & SIKLUS II & VARIABEL \\
\hline Skor Nilai & 2040 & 2350 & 2670 & Prestasi Belajar IPS \\
Rata Rata Kelas & 60,00 & 69,11 & 78,52 & Dengan \\
Persentase Ketuntasan & $26,47 \%$ & $73,52 \%$ & $94,11 \%$ & KKM $=70$ \\
\hline
\end{tabular}

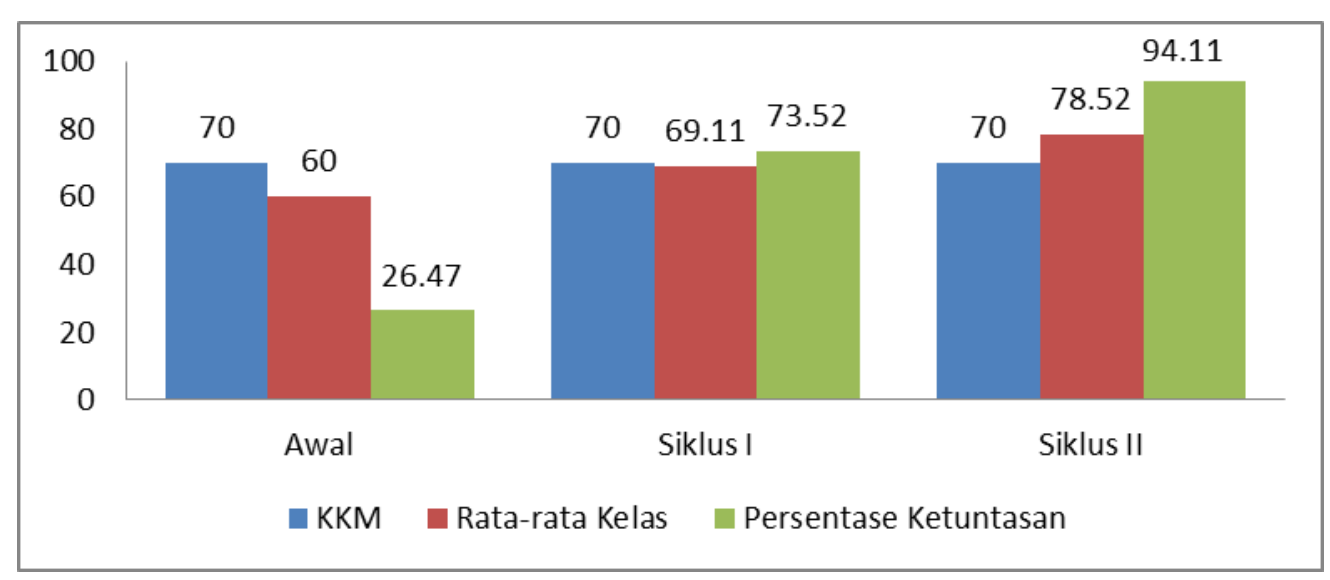

Gambar 2. Grafik Histogram Prestasi Belajar IPS Siswa Kelas III A Semester II Tahun Pelajaran 2018/2019 SD Negeri 3 Ubud

Data awal yang diperoleh dengan rata-rata 60,00 dengan ketuntasan belajar hanya mencapai $26,47 \%$ menunjukkan bahwa kemampuan anak/siswa dalam mata pelajaran IPS masih sangat rendah mengingat kriteria ketuntasan belajar siswa untuk mata pelajaran ini di SD Negeri 3 Ubud adalah 70,00. Hal ini dikarenakan metode yang digunakan masih bersifat konvensional, dan guru hanya berceramah dalam menyampaikan materi sehingga siswa kesulitan dalam menerima pelajaran. Dengan nilai yang sangat rendah seperti itu maka peneliti mengupayakan untuk dapat meningkatkan prestasi belajar siswa menggunakan model Kooperatif tipe STAD dengan media gambar. Akhirnya dengan penerapan model Kooperatif tipe STAD dengan media gambar yang benar sesuai teori yang ada, peningkatan rata-rata prestasi belajar siswa pada siklus I dapat diupayakan dan mencapai rata-rata 69,11. Namun rata-rata tersebut belum maksimal karena hanya 25 siswa memperoleh nilai di atas KKM sedangkan yang lainnya belum mencapai KKM. Sedangkan prosentase ketuntasan belajar mereka baru mencapai $73,52 \%$. Hal tersebut terjadi akibat penggunaan model Kooperatif tipe STAD dengan media gambar belum maksimal dapat dilakukan disebabkan penerapan model/metode tersebut baru dicobakan sehingga guru masih belum mampu melaksanakannya sesua alur teori yang benar.

Pada siklus ke II perbaikan prestasi belajar siswa diupayakan lebih maksimal dengan peneliti membuat perencanaan yang lebih baik, menggunakan alur dan teori dari model Kooperatif tipe STAD dengan media gambar dengan benar dan lebih maksimal. Peneliti giat memotivasi siswa agar giat belajar, memberi arahan-arahan, menuntun mereka untuk mampu menguasai materi pelajaran pada mata pelajaran IPS lebih optimal. Akhirnya dengan semua upaya tersebut peneliti mampu meningkatkan prestasi belajar siswa pada siklus II menjadi rata-rata 78,52 dengan ketuntasan belajar mencapai $94,11 \%$. Upaya-upaya yang maksimal tersebut menuntun pada suatu keberhasilan bahwa penggunaan model pembelajaran Kooperatif tipe STAD dengan media gambar mampu meningkatkan prestasi belajar IPS siswa kelas III A semester II SD Negeri 3 Ubud tahun pelajaran 2018/2019.

Hasil penelitian ini sejalan dengan hasil penelitian yang dilakukan oleh Karyanto (2013) yang berjudul Penggunaan Media Gambar Dalam Model Pembelajaran Kooperatif Tipe Student Teams Achievement Division (STAD) Untuk Meningkatkan Hasil Belajar Siswa Pada Mata Pelajaran IPS Kelas IV SDS Baptis Pengharapan Tegalsari Surabaya. Pada kegiatan pembelajaran aktivitas guru mengalami 
peningkatan dari siklus I, siklus II dan siklus III. Pada siklus I aktivitas guru mencapai 60,7\%, pada siklus II aktivitas guru mencapai $75 \%$ dan pada siklus III aktivitas guru mencapai $89,3 \%$. Sedangkan aktivitas siswa pada siklus I mencapai $65,6 \%$, siklus II aktivitas siswa mencapai $74,5 \%$ dan siklus III aktivitas siswa mencapai $92,1 \%$. Data hasil tes siswa pada siklus I mencapai $66,7 \%$, siklus II mencapai $78,8 \%$ dan pada siklus III mencapai 87,9\%. Diakhir pelajaran dibagikan lembar angket untuk mengetahui respon siswa. Persentase angket mencapai $>80 \%$. Dari hasil tersebut dapat disimpulkan bahwa penerapan model pembelajaran kooperatif tipe STAD dapat meningkatkan hasil belajar siswa kelas IV SDS Baptis Pengharapan Surabaya.

\section{Simpulan Dan Saran}

Pemicu rendahnya prestasi belajar ada pada faktor model/metode yang digunakan guru dalam proses pembelajaran.Untuk itu penggunaan model/ metode yang sifatnya konstruktivis sangat diperlukan. Dalam hal ini peneliti menerapkan model pembelajaran Kooperatif tipe STAD dengan media gambar sebagai solusi untuk memecahkan permasalahan yang ada.

Dari hasil refleksi yang telah disampaikan di Bab IV dan dengan melihat semua data yang telah dipaparkan, dapat disampaikan bahwa pencapaian tujuan penelitian di atas dapat dibuktikan dengan argumentasi sebagai berikut.

a) Dari data awal ada 25 siswa mendapat nilai di bawah KKM dan pada siklus I menurun menjadi 9 siswa dan siklus II hanya 2 ada siswa mendapat nilai di bawah KKM.

b) Nilai rata-rata awal 60,00 naik menjadi 69,11 pada siklus I dan pada siklus II naik menjadi 78,52.

c) Dari data awal siswa yang tuntas hanya 9 orang sedangkan pada siklus I menjadi lebih banyak yaitu 25 siswa dan pada siklus II sebanyak 32 siswa sudah mampu memenuhi KKM.

Paparan di atas membuktikan bahwa model pembelajaran Kooperatif tipe STAD dengan media gambar dapat memberi jawaban sesuai tujuan penelitian ini, yaitu penggunaan model pembelajaran Kooperatif tipe STAD dengan media gambar mampu meningkatkan prestasi belajar IPS siswa kelas III A semester II SD Negeri 3 Ubud tahun pelajaran 2018/2019. Semua ini dapat dicapai karena model pembelajaran Kooperatif tipe STAD dengan media gambar sangat efektif diterapkan dalam proses pembelajaran yang mengakibatkan siswa aktif, antusias dan dapat memahami materi yang diajarkan sehingga prestasi belajar siswa menjadi meningkat

\section{Daftar Rujukan}

Arends, Richard I. 2004. Learning to Teach. Sixth Edition. New York: McGraw-Hill.

Asikin dan Pujiadi. Lembaran Ilmu Kependidikan Jilid 37, NO. 1, Juni 2008. Pengaruh Model Pembelajaran Matematika Creative Problem Solving (CPS) Berbantuan Cd Interaktif Terhadap Kemampuan Pemecahan Masalah Pada Siswa Kelas XSMA Negeri 1 Semarang. FMIPS Unnes.

Aunurrahman. 2009. Belajar dan Pembelajaran. Bandung: Alfabeta.

Buchori, 2012. Artikel Hasil Penelitian. Pengaruh Model Pembelajaran Matematika Creative Problem Solving (CPS) Berbantuan Software GeogebraTerhadap Kemampuan Pemecahan Masalah Pada Siswa SMA. Fakultas Pendidikan Matematika Dan Ilmu Pengetahuan Alam. IKIP PGRI Semarang.

Dewi, E P. 2008. Skripsi.Pengaruh Penggunaan model pembelajaran Creative Problem Solving (CPS) dalam Pembelajaran IPS terhadap Kemampuan Penalaran Adaptif Matematika Siswa SMA. FPMIPS UPI. Bandung.

Karyanto. 2013. Penggunaan Media Gambar Dalam Model Pembelajaran Kooperatif Tipe Student Teams Achievement Division (STAD) Untuk Meningkatkan Hasil Belajar Siswa Pada Mata Pelajaran IPS Kelas IV SDS Baptis Pengharapan Tegalsari Surabaya. E-Jurnal Penelitian Pendidikan Guru Sekolah Dasar Unesa Volume 1 Nomor 1.

Maulana, Panji. 2017. Penerapan Pembelajaran Kooperatif Tipe Stad (Student Team Achievement Division) Untuk Meningkatkan Kemampuan Membaca Pemahaman Di Sekolah Dasar . Jurnal Pesona Dasar Vol. 5 No.2, Oktober 2017 
Monawati. 2016. Upaya Meningkatkan Hasil Belajar Siswa Melalui Lesson Studypada Penjumlahan Pecahan Di Kelas Iv Sdn Lamsayeun . Jurnal Pesona Dasar Universitassyiah Kuala Vol. 3 No.4, Oktober 2016

Rahman, B. 2009.Skripsi.Perbandingan Kemampuan Koneksi Matematik Siswa yang Pembelajarannya Menggunakan Model Creative Problem Solving (CPS) dengan Siswa yang Pembelajarannya Menggunakan Model Konvensional. FPMIPS UPI. Bandung.

Purwanti, Sri. 2018. Penerapan pembelajaran kooperatif tipe STAD untuk meningkatkan motivasi dan hasil belajar PKn . Jurnal Ilmu-Ilmu Sosial Vol. 15 No. 2 Tahun 2018

Thahir, Andi. 2014. Pengaruh Bimbingan Belajar Terhadap Prestasi Belajar Siswa Pondok Pesantren Madrasah Aliyah Al-Utrujiyyah Kota Karang . Jurnal Bimbingan dan Konseling 01 (2) (2014).

Wardana, Ika. 2017. Penerapan Model Pembelajaran Kooperatif Tipe Student Team Achivement Division (STAD) untuk Meningkatkan Hasil Belajar Siswa Kelas XI IPA Avogadro SMA Negeri 2 Pangkajene (Studi pada Materi Asam Basa). Jurnal Chemica Vo/. 18 Nomor 1 Juni 2017 